\title{
Rural Land Market, Livelihood and Welfare among Households in Oyo State, Southwest Nigeria
}

\author{
Olubunmi O. Alawode \\ Correspondence: Olubunmi O. Alawode, Department of Agricultural Economics, University of Ibadan, Nigeria. \\ Received: December 18, 2020 \\ Accepted: January 12, 2021 \\ Online Published: January 22, 2021 \\ doi:10.11114/bms.v7i1.5137 \\ URL: https://doi.org/10.11114/bms.v7i1.5137
}

\begin{abstract}
With rapid population growth and resulting increased land fragmentation, landholding becomes smaller, negatively impacting on the living standard of rural households. Thus, the need to understand the potentials of land markets to improve rural households' access to land through the adjustment of households' landholding for livelihood activities, and its consequent effect on their welfare. This paper examined the relationship between rural land market, livelihood and welfare among households in Oyo state, Southwest Nigeria. Using a structured questionnaire, a survey was conducted on a sample of 200 respondents, who were selected through multistage sampling procedure. Descriptive statistics, Land Market Index (LMI), Tobit model and multiple regression analysis were used to analyse the primary data. Results show that majority (74.0\%) of households were involved in crop farming with mean income of $\$ 53$ 833.33 ( \pm 26784.560 ), which was relatively higher than livestock $\$ 31567.08$ ( \pm 20897.47$)$. The mean total monthly expenditure was 26548.50 ( \pm 8945.5692$)$. Identified land transaction methods include purchase (76.3\%), lease $(19.8 \%$ ), and rent (3.9\%). On the average, $97.0 \%$ of land held by households were acquired through market (LMI $=0.97)$. Sex and household status had significant positive effects on the extent of households' participation in land market at $\mathrm{p}<0.01$. Also, LMI, crop farming and livestock farming had significant positive effect on households' welfare. Obtaining land through market for livelihood activities promotes households' welfare. Rural land market and livelihood activities have significant positive effects on the welfare of farmers. There is need for Government to facilitate formal land markets in rural areas.
\end{abstract}

Keywords: Land Market Index, Welfare, Livelihood Income, Expenditure Pattern, Rural Households

\section{Introduction}

Land is a unique, valuable and immovable resource of limited quantity. It is one of the most precious assets. In traditional societies, it is regarded as a common good and cannot be alienated or sold (Idowu, Alawode, Alimi, \& Kassali, 2007), while in the modern communities, it is a commodity that is desired and can be exchanged (Wily, 2003). Land is one of the production factors, it constitutes the fulcrum for food production as well as provision of shelter and utilities for the manufacture of foods and the establishment of institutions to meet the basic needs of modern communities (Lasun, 2006). Land does not only serve as the most basic aspect of subsistence for many people around the world, it also contains valuable structures and natural resources on it or beneath it. According to World Bank (2011), the percentage of agricultural land area in Nigeria was measured at $83.67 \%$ hence, agriculture constitutes the largest use of land.

Land market exists when and wherever it is possible to exchange rights in land for agreed amounts of money or services rendered (Idowu et al., 2007). Therefore, any land transfer process that is done on transaction basis or in which money is exchanged, can be referred to as land market. Land markets are generally regulated through land tenure and land administration systems. According to Food and Agriculture Organization (FAO, 2005), land tenure is the expression of relationship between man and land on one hand, and between man and man on the other hand. It is a bundle of entitlements (rights and duties) concerning the use of land resources (Kironde, 2000). The basic role of land market is to allow for permanent or temporary transfers of land between potential land users, to improve the welfare of landless farmers (Alawode, Adewusi \& Abegunde, 2018a).

Welfare is said to be the wealth, happiness and fortunes of a person or group. Broadly, economic welfare is the level of prosperity and standard of living of a group of persons. Welfare can be related both to the individual and to the collective. It specifically refers to utility gained through the achievement of material goods and services; it is usually 
measured by consumption or income from livelihood activities (Moratti \& Natali, 2012).

A livelihood comprises the capabilities, assets (stores, resources, claims and access) and activities required for a means of living (Chambers \& Conway, 1992). A household is said to be a group of people that dwell together and basically eat from the same pot. Rural households have diverse livelihood strategies, encompassing a range of activities. For most of the rural households, agriculture is a key element of their livelihood strategies. However, many are also engaged in non-agricultural activities, including micro enterprises (agro-processing, trading and other off-farm occupations) in which land is usually acquired to carry out these activities. Households seek to ensure their food requirements and to generate the income they require to satisfy their immediate consumption needs, social purposes and investments, and this also has an impact on their welfare, which is said to be the provision of a minimal level of wellbeing and social support for all citizens.

\subsection{Statement of Research Problem}

Omokhudu (2008) noted that Nigeria has abundant cultivable land area of about 72 million hectares; only 34 million hectares or about $50 \%$ is put into cultivation. It calls for concern that with this large cultivable land area which are yet to be utilized, a very large number of Nigerian farmers have small landholdings and small farm sizes. The reason ascribed to this is that land is concentrated in the hands of few individuals who had primarily acquired large hectares of land through purchase (Burgress, 2001). Land market is a framework in which those seeking land and owning or controlling it are brought into transaction in order that land seekers will gain access to land. Also, land market is expected to redistribute land from farmers not using them to those who need them for agricultural production. Access to land by land seekers is expected to have positive impact on agricultural production (Alawode et al., 2018a), and as a result, welfare of farmers.

Rural households have, from time to time, been riddled with problems of land market, especially in the area of transaction cost, and most often, these transaction costs that impede land transfers have been known to decrease the efficiency of livelihood activities and most importantly, agricultural production. Land market, in developing countries, are still characterized by the existence of significant transaction cost, thereby constraining access to land for rural households who are willing to start up or enlarge their farms, and reinforcing the persistence and dominance of large scale farms (Vraken, 2002). According to Vranken (2002), there have been conflicting views on how well those who are poor can benefit from land market because the formal systems that can enable individuals or households to have access to capital may not operate very effectively for poor households and small farms in the rural areas. Thus, there is a danger that land markets may lead to more poor people becoming landless with the concentration of land into the hands of the rich.

Continuous increase in population, coupled with non-agricultural purposes which compete for land use, has a resultant effect of reducing the returns to land in terms of output; this would further expose the rural households in the country to poor economic conditions thereby negatively impacting on their living standard and food security situation (Bamire \& Fabiyi, 2002). Land is one of the scarce resources that remain unequally distributed in Nigeria. With rapid population growth resulting in increased land fragmentation; land holding is becoming smaller, that is, unable to sustain the households adequately. World Bank (2003) noted that majority of the rural population produces $84 \%$ of total agricultural output. From the Food and Agricultural Organization Statistical database (FAOSTAT, 2012), the per capita landholding is projected to decline from 0.635 hectare per person in year 2006 to 0.4467 hectare in year 2020, while the number of persons per kilometer square is expected to increase from 1577.06 to 2243.03 for the same period. Thus, the need to accurately understand the potentials of land markets to improve rural households' access to land through the adjustment of households' landholding for livelihood activities, and its consequent effect on their welfare.

\subsection{Objectives of the Study}

The main objective of this paper is to examine the relationship between rural land market, livelihood and welfare of households in Oyo state, Southwest Nigeria. The specific objectives are to:

i. examine livelihood activities and income among rural households;

ii. identify the pattern of expenditure of rural households;

iii. analyse the participation of rural households in land market and the determinants of the extent of households' participation in land market;

iv. measure the effects of participation in land market and livelihood income on the welfare of rural households.

\subsection{Justification for the Study}

Land markets are important because all economic development depends to some degree on the availability of land. Most of rural households' livelihood activities require the use of land at one point or the other, hence the need for 
involvement in land market. The development of land markets has historically been closely linked to the development of a nation, its economic well-being and the quality of life of its citizens (Alawode et al., 2018a). Although, Kironde (2000) observed that the concept of land market has not received sufficient attention in the process of access to land in Africa and this is perhaps because both colonial and post-colonial policy makers believed that market transactions in land did not take place within African societies. However, according to Vraken (2002), properly functioning rural land markets are of vital importance to the development of rural areas, and also for agricultural growth. Sequel to this, it is very important that necessary conditions are put in place to encourage the participation of rural households in land market to increase their involvement in livelihood activities, in order to increase their income generation and improve their welfare.

Antwi (2002) also opined that land transactions are the optimal solution for crisis in an environment where the formal system is riddled with excessive bureaucracy and cost. This paper focuses on rural households' participation in land markets on the basis of their livelihood activities, and how this affects their income generation and welfare. This study concentrates on how livelihood activities and income of rural farmers, as well as their welfare status, can be positively enhanced through their participation in land market. The results of this study can serve as information for policies that can help improve rural households' participation in land market with a view to improving their welfare.

\section{Literature Review}

\subsection{Theoretical Framework}

\subsubsection{New Institutional Economic Theories of Land Markets}

Although, still outnumbered by the many neo-classical studies on land and property markets, there is a growing literature that takes a new institutional economic perspective (Buitelaar, 2007; Alexander, 2001). In these approaches, institutional explanations are not used to explain anomalies in market outcomes, but are made the key subject of study so as to understand how market processes work. New institutional economics starts from the observation that markets do not function without friction. We live in a world with imperfect information, uncertainty and opportunism (Williamson, 1975). As a result, transaction costs arise that prevent the market from functioning perfectly. Transaction costs can be defined as the costs of running the economic system (Arrow, 1969). Institutions can facilitate exchanges and in that way reduce transaction costs. If such costs were zero, institutions would not be necessary, according to new institutional economics. The main institutional concepts are property rights, which are the institutions that determine the nature of the good that is transacted, and governance structures, which are the institutional frameworks through which property rights are exchanged.

New institutional economics tries to explain something which neo-classical economics regards as unproblematic; the mechanisms by which actors interact. It offers a set of theories that claim to be generalizable, and which can be tested empirically. Nevertheless, new institutional economics has its limitations (Buitelaar, 2007). Only the institutions that directly affect the transaction (that is, the property rights and the governance structures) are taken into account while the general institutional environment or context, the laws and customs, is taken as given (Williamson, 1996). This overall structure shapes the cost of transacting at the individual contract level, and when economists talk about efficient markets, they have simply taken for granted an elaborate framework of constraints

\subsubsection{Theory of Activity}

Activities are the particular uses to which productive assets are utilized. Activities are ex ante flows of assets services that map the stock concept of assets into the ex post flows of income. For example, livestock can be allocated to crop production, providing transport services (pulling carts), milk production, or to reproduction (calf breeding). All these activities generate income flows. Land can be allocated to crop production, livestock production, manufacturing, commerce, or services (recreation). Activities use productive assets, often a combination of multiple complementary assets, to generate income. For example, rice income is the product of allocation of land, labour, and perhaps cash (transformed into purchased inputs), irrigation or other farm equipment, or animals (for traction and/or manure) (Reardon \& Vosti, 1995).

\subsection{Empirical Review}

Idowu et al. (2007) carried out an analysis of agricultural land market in Ondo state of Nigeria. The study analysed the extent and level of development of agricultural land market in Ile-Oluji/Oke-Igbo local government area of Ondo state. Primary data were obtained from 200 respondents (100 migrant farmers and 100 landowners) and secondary data were also obtained for the study. Descriptive statistics and Markov chain model were used to analyse the data. The results showed that most of the respondents were full-time farmers involved in cocoa farming and $41 \%$ of the farm plots covered by the study were involved in land market transactions. It was concluded that Agricultural land markets within the study area was capable of allocating land from land surplus landowners, to land deficient migrant farmers, and the 
customary tenure systems provided adequate security of rights to migrant farmers who have acquired lands within the system.

Sallawu, Tanko, Coker \& Sadiq (2016) investigated livelihood and income diversification strategies among rural farm households in Niger State, Nigeria. Data were obtained from administering questionnaire to 287 farming households who were selected using multi-stage sampling procedure. Data were analysed using descriptive statistics and Herfindahl diversification index. It was shown that farm income accounted for $63 \%$, while off farm income accounted for $37 \%$ of the total income of the sampled farm households. Majority of the farm households had more than one source of income. It was therefore recommended that farm households should diversify their sources of livelihood into non-farm activities available in the study area so as to increase their earnings, to bridge the poverty gap and improve their livelihood. Also, the level of literacy among rural farm households and financial markets should be looked into by the Government when formulating policy and developmental issues.

Alawode, Oluwatayo \& Abdullahi (2017) examined income diversification, inequality and poverty among rural households in Oyo state, Nigeria. Using structured questionnaire, cross-section data were generated from a sample of 200 households, who were selected through multi-stage sampling procedure. Data were analysed using descriptive statistics, diversification index, Gini coefficient, FGT poverty index, and the Probit regression model. Results showed a mean income diversification index of 1.22, implying that majority of the respondents had multiple streams of income and crop farming had the largest share $(90 \%)$ in total income. The mean income of households was $777613.2 \pm 83$ 575.01, and Gini coefficient of $0.48,0.46$, and 0.39 were obtained for total income, non-agricultural income, and agricultural income respectively. The poverty line and mean per capita expenditure were $\$ 6490.50$ and $\$ 9735.74$, respectively, giving the head count ratio of 53.5\%, implying that more than half the households were poor while $46.5 \%$ were regarded as non-poor. Poverty gap was 0.214. Age, secondary occupation, and farm size had significant inverse relationship with poverty status. Having primary and secondary income sources reduces poverty. Rural households should be encouraged to remain in farming, especially crop farming, and through skill acquisition, household members can be encouraged to diversify into other income generating activities.

Alawode et al. (2018a) analysed land market and crop commercialization in Nigeria using General Household Survey (Living Standard Measurement Survey) panel data for the post-planting and post-harvest periods of 2015 and 2016 cropping seasons. Results indicate that family inheritance is still the dominant means of land acquisition in Nigeria (70.3\%). However, results point to the fact that farmers acquired land through transaction; $12.5 \%$ of the farmers participated in land market (outright purchase and rented for cash or kind). Majority (84.5\%) of the farmers cultivated between 2 and 5 hectares, and the mean farm size of 1.1 ha $( \pm 1.49)$, indicating that majority of farmers in Nigeria operate on small scale. This is a pointer to the fact that Nigerian farmers need more land for cultivation from land owners that are not putting their land into productive use. Hence, the need for land market. The emerging dynamic land markets will complement the Government based land allocation which are oftentimes characterized by inconsistency in land accessibility

\section{Research Methodology}

\subsection{The Study Area}

The study was carried out in Oyo state in the Southwest geopolitical zone of Nigeria. Most of the rural dwellers in the state are involved in different livelihood activities, most especially, agriculture related activities that require the use of land. Also, due to the presence of migrant farmers in the state, there is need for their involvement in land market. Oyo state covers approximately an area of 28454 square kilometres of land mass and a population of 6617720 as at 2006 census. The state is located on latitude $8.0000^{\circ} \mathrm{N}$ and latitude $4.0000^{\circ} \mathrm{E}$ and consists of 33 Local Government Areas (LGAs). The vegetation pattern of Oyo State is that of rain forest in the south and guinea savannah in the north. The climate in the state also favours the cultivation of crops like maize, yam, cassava, millet, rice, plantain, cocoa tree, palm tree and cashew. Other livelihood activities such as teaching, trading, transportation, artisanship, basket weaving, and etcetera, are also found among the people of the state (Oyo State Official Website, 2019).

\subsection{Sources and Methods of Data Collection}

Primary data used for this study were generated from a survey of 200 respondents. Structured questionnaire was used to obtain data on farmers' socioeconomic characteristics such as age, sex, immigrant status, marital status, years of formal education, household size, status of respondents in households, main occupation, and so on. Data on expenditure on food items, health, education, clothing and rent were obtained. Data were also obtained on plot characteristics; no of plots held, size of plots, no of plots locations, plot acquisition and transaction methods, and etcetera. Information on various livelihood activities and income earned from livelihood activities were also obtained. 


\subsection{Sampling Procedure}

A multistage sampling procedure was used. The first stage involved a purposive selection of 3 Local Government Areas (Lagelu, Ibarapa East and Akinyele) in Oyo state due to the high concentration of migrant farmers in these LGAs, and their involvement in various livelihood activities. The second stage involved the random selection of 7 villages each from Lagelu and Ibarapa East LGAs and six villages from Akinyele LGA based on size. The last stage involved the random selection of 10 farmers in each of the selected villages, giving a total of 200 respondents sampled for the study.

\subsection{Methods of Data Analysis}

The methods of data analysis include descriptive statistics, Land Market Index (LMI), Tobit model, and multiple regression analysis.

\subsubsection{Descriptive Analysis}

Livelihood activities and income among rural households were analysed using descriptive statistics such as frequency counts, percentages and means, and the results were presented in frequency distribution tables. Also, expenditure of rural households was analysed using descriptive statistics.

\subsubsection{Land Market Index}

According to Olaniran (2015), Alawode, Olaniran \& Abegunde (2016), Alawode et al. (2018a), and Alawode, Abegunde \& Abdullahi (2018b), the extent to which households participate in land market was estimated using land market index (LMI) which is defined as;

$$
\begin{aligned}
& L M I_{c}=\frac{\text { Total land area acquired by households through market for crop farming }}{\text { total area of land planted to crops }} \\
& L M I_{L}=\frac{\text { Total land area acquired } \text { by households through market for livestock farming }}{\text { total area of land for livestock farming }} \\
& L M I_{h i}=\frac{\text { Total land area acquired by household } i \text { through market }}{\text { total area of land held by household } \boldsymbol{i}} \\
& L M I_{h}=\frac{\text { Total land area acquired by all households through market }}{\text { total area of land held by households }} \\
& \mathrm{LMI}_{\mathrm{c}}=\text { land market index for crop farming } \\
& \mathrm{LMI}_{\mathrm{L}}=\text { land market index for livestock farming } \\
& \mathrm{LMI}_{\mathrm{hi}}=\text { land market index for household } i \\
& \mathrm{LMI}_{\mathrm{h}}=\text { land market index of all households } \\
& \mathrm{LMI} \text { ranges between } 0 \text { and } 1(0 \leq \mathrm{LMI} \leq 1)
\end{aligned}
$$

$\mathrm{LMI}=1$, if all plots of land held by the household are acquired through transaction based method

$\mathrm{LMI}=0$, if none of the plots of land is acquired through transaction based method

\subsubsection{Tobit Model}

The determinants of the extent of participation of households in land markets were estimated using Tobit model. Tobit model is used to describe the relationship between a non-negative dependent variable $\mathrm{Y}$ and an independent variable or vector X (Tobin, 1958). Tobit model is appropriate for this analysis because the dependent variable (land market index), is censored at lower boundary of 0 .

The standard Tobit model is defined as;

$\mathrm{Y}_{\mathrm{i}}=\beta+\mathrm{X}_{\mathrm{i}} \beta+\varepsilon_{\mathrm{t}}$

Such that $Y$ can be observed to be

$\mathrm{Y}_{\mathrm{i}}=\left\{\mathrm{Y}_{\mathrm{i}}^{*}\right.$ if $\mathrm{Y}_{\mathrm{i}}^{*}>0$, and 0 if $\left.\mathrm{Y}_{\mathrm{i}} \leq 0\right\}$

$\mathrm{Y}$ is the response variable, LMI, which could take the values between 0 and 1

$\mathrm{X}_{\mathrm{i}}$ is the vector of explanatory variables

$\varepsilon_{t}$ is the error term

The model is explicitly defined as 
$\mathrm{Y}=\beta_{0}+\beta_{1} \mathrm{x}_{1}+\beta_{2} \mathrm{x}_{2}+\beta_{3} \mathrm{x}_{3}+\beta_{4} \mathrm{x}_{4}+\beta_{5} \mathrm{x}_{5}+\beta_{6} \mathrm{x}_{6}+\beta_{7} \mathrm{x}_{7}+\beta_{8} \mathrm{x}_{8}+\beta_{9} \mathrm{X}_{9}+\varepsilon_{\mathrm{t}}$

Where $\mathrm{Y}$ is the dependent variable $=\mathrm{LMI}(0 \leq \mathrm{LMI} \leq 1)$

$\mathrm{X}_{1}=\operatorname{sex}(1=$ male, $0=$ female $)$

$\mathrm{X}_{2}=$ age in years

$\mathrm{X}_{3}=$ immigrant status $(1=$ native, $0=$ non- native $)$

$\mathrm{X}_{4}=$ years of schooling

$\mathrm{X}_{5}=$ household size (number)

$\mathrm{X}_{6}=$ total land size (area of total land holding in hectares)

$\mathrm{X}_{7}=$ household income in Naira

$\mathrm{X}_{8}=$ access to credit $(1=\mathrm{yes}, 0=$ no)

$\mathrm{X}_{9}=$ status in household ( $1=$ head, $0=$ otherwise)

\subsubsection{Multiple Regression Analysis}

The effects of land market and livelihood income on the welfare of rural households was examined using multiple regression analysis.

The linear regression model in explicit form is:

$Y=\beta_{0}+\beta_{1} X_{1}+\beta_{2} X_{2}+\beta_{3} X_{3}+\beta_{4} X_{4}+\beta_{5} X_{5}+\beta_{6} X_{6}+\beta_{7} X_{7}+\beta_{8} X_{8}+\beta_{9} X_{9}+\beta_{10} X_{10+} \beta_{11} X_{11+} \varepsilon_{t}$

Where $Y=$ welfare (measured by total expenditure of households in Naira)

$\mathrm{X}_{1} \ldots \mathrm{X}_{11}$ are the explanatory variables

$\mathrm{X}_{1}=$ age in years

$\mathrm{X}_{2}=$ household size (number)

$\mathrm{X}_{3}=$ marital status $(1=$ married, $0=$ otherwise $)$

$\mathrm{X}_{4}=$ land market index $(0 \leq \mathrm{LMI} \leq 1)$

$\mathrm{X}_{5}=$ total land size (total land holding in hectare)

$\mathrm{X}_{6}=$ access to credit $(1=\mathrm{yes}, 0=$ no $)$

$\mathrm{X}_{7}=$ immigrant status ( $1=$ native, $0=$ non- native $)$

$\mathrm{X}_{8}=$ years of schooling

$\mathrm{X}_{9}=$ household status ( $1=$ head, $0=$ otherwise $)$

$\mathrm{X}_{10}=$ crop farming ( $1=\mathrm{yes}, 0=$ otherwise $)$

$\mathrm{X}_{11}=$ livestock farming ( $1=$ yes, $0=$ otherwise $)$

$\varepsilon_{\mathrm{t}}$ is the error term

\section{Results and Discussions}

\subsection{Livelihood Activities and Income among Rural Households}

The various livelihood activities found in the study area and the income generated by rural households from their respective livelihood activities are presented in Table 1. The main concern in this study is farming livelihood activities as they require the use of land, hence the involvement of households in land market. There are also other livelihood activities found amongst the rural households in the study area asides farming. 
Table 1. Livelihood activities among rural households

\begin{tabular}{lll}
\hline Livelihood activity & Frequency $\mathbf{n = 2 0 0}$ & $\mathbf{\%}$ \\
\hline Crop farming & 148 & 74.0 \\
Livestock farming & 35 & 17.5 \\
Crop and livestock farming & 17 & 8.5 \\
Other livelihood activities & & \\
Artisanship & 6 & 3.0 \\
Produce buying & 5 & 2.5 \\
Trading & 5 & 2.5 \\
Transportation & 1 & 0.5 \\
Clergy & 1 & 0.5 \\
Security & 1 & 0.5 \\
Produce buying and trading & 1 & 0.5 \\
\hline
\end{tabular}

Source: Field Survey, 2019

Table 1 shows that majority (74.0\%) of the households were involved in crop farming, less than a quarter (17.5\%) were involved in livestock farming and minority (8.5\%) were involved in both crop farming and livestock farming. This may be due to increase in market demand for crop produce than for livestock produce or probably because soil properties in the study area favours an overall increase in yield of crop produce. The descriptive analysis shows that $3.0 \%$ of those involved in other livelihood activities were involved in artisanship, produce buying and trading $(2.5 \%$ each), and other activities such as transportation, clergy, security or combination of produce buying and trading $(0.5 \%$ each $)$.

The income generated by households from all the livelihood activities is presented in Table 2.

Table 2. Income Generated by Rural Households from all Livelihood Activities

\begin{tabular}{llll}
\hline Livelihood Activity & Minimum & Maximum & Mean \\
\hline Crop Farming & 5800 & 125000 & $53833.33( \pm 26784.56)$ \\
Livestock Farming & 3500 & 80000 & $31567.08( \pm 20897.47)$ \\
All livelihood activities & 6500 & 130000 & $80536.00( \pm 12423.31)$ \\
\hline
\end{tabular}

Source: Data analysis, 2019

From the results, the mean income indicates that on the average, farmers generated $\$ 8056$ per month from all of the livelihood activities they engaged in. Also, on the average, a crop farmer generated $\$ 53833$ per month, and a livestock farmer generated $\$ 31567$ per month. The mean income for crop farming activities ( $\$ 53$ 833) is seen to be relatively higher than that of livestock ( $\mathrm{N} 31$ 567). This may imply that crop farming is relatively more income yielding than livestock farming in the study area, the reason why people are involved more in crop than livestock farming. Also, being involved in farming (crop and livestock) and other sources of income brings higher levels of income, considering the mean of $\$ 80536$ for total income from all livelihood activities.

\subsection{Pattern of Expenditure of Rural Households}

The pattern of expenditure on food and non-food items among the rural households is presented in Table 3 .

Table 3. Pattern of Expenditure of Rural Households

\begin{tabular}{lllllll}
\hline Expenditure item & Min (\$) & Max (\$) & $\begin{array}{l}\text { Total by } \\
\text { (\$/month) }\end{array}$ & households & Mean & Standard Deviation \\
\hline $\begin{array}{l}\text { Food items } \\
\text { Non-food items }\end{array}$ & 500 & 12000 & 886000 & 4430.00 & \pm 1532.82 \\
Health & 0 & 3000 & 97620 & & \\
Education & 0 & 40000 & 2589700 & 488.10 & \pm 368.05 \\
Rent and house repairs & 0 & 18500 & 1148820 & 12948.50 & \pm 5276.84 \\
Clothing & 400 & 15000 & 587550 & 2937.75 & \pm 4711.87 \\
Total Expenditure & 000 & 65000 & 5309700 & 5744.10 & \pm 2411.16 \\
\hline
\end{tabular}

Source: Data Analysis, 2019 
From the results in Table 3, the non-food items include health, education, clothing, and house rent/repairs. Results show that households spent more on education ( $\$ 12$ 948.50) than any of the non-food items. This implies that educating members of households was highly valued among them. Expenditure on clothing (\$5744.10) was observed to be higher than expenditure on food items ( $\$ 430$ ), this may be due to the fact that most households were involved in crop farming, hence did not need to spend much in purchasing food items. Expenditure on house rent and repairs ( $\$ 2937.75$ ) was also not high, compared to others, because majority of the farmers were house owners, hence did not have to pay rent, but spent only on house repairs. The least expenditure (488.10) was observed on health, suggesting that majority of the households made use of orthodox treatments that could easily be sourced from the environment when they are ill rather than spending on modern drugs that would cost more.

The highest total expenditure was $\$ 65000.00$ while the lowest was $\$ 600.00$ monthly. The mean total income ( $\$ 80$ 536.00) from Table 2 was higher than the mean total expenditure ( $\$ 26$ 548.50), which shows that households did not spend as much as they earned which can imply that probably they saved more from their income.

4.3 Participation of Rural Households in Land Market and the Determinants of the Extent of Households' Participation in Land Market

4.3.1 Land Acquisition and Transaction

Means of land acquisition by households and the transaction-based methods are presented in Table 4 .

Table 4. Land Acquisition and Transaction Methods

\begin{tabular}{lll}
\hline Variable & Frequency & \% \\
\hline Types of Acquisition methods & 158 & 72.0 \\
Purchase & 41 & 18.6 \\
Lease & 8 & 3.6 \\
Rent & 8 & 3.6 \\
Gift & 5 & 2.2 \\
Inheritance & 220 & 100.0 \\
Total & & \\
\hline Transaction based methods & 158 & 76.3 \\
Purchase & 41 & 19.8 \\
Lease & 8 & 3.9 \\
Rent & 207 & 100.0 \\
Total & &
\end{tabular}

Source: Field Survey, 2019

As shown in Table 4, there were 5 means of land acquisition found in the study area; inheritance, gift, purchase, rent and lease. From these, 3 types of transaction based methods were identified; purchase, rent and lease. The results show that majority (72.0\%) of the farm plots acquired by the farmers were through purchase method, while $18.6 \%$ of the farm plots were acquired by lease method. The least proportion (2.2\%) of the plots was acquired by inheritance, suggesting that there were many migrant farmers in the study area. 


\subsubsection{Socio-Economic Characteristics of Respondents}

The socio-economic characteristics of respondents in the study area are presented in Table 5.

Table 5. Respondents' Socio-economic Characteristics

\begin{tabular}{lll}
\hline Variable & Frequency $\mathbf{( n = 2 0 0 )}$ & \% \\
\hline Sex & 168 & 84.0 \\
Male & 32 & 16.0 \\
Female & & \\
\hline Immigration status & 192 & 96.0 \\
Non-native & 8 & 4.0 \\
Native & & \\
\hline Marital status & 193 & 96.5 \\
Married & 4 & 2.0 \\
Widowed & 3 & 1.5 \\
Single & 0 & 0.0 \\
Divorced & & \\
\hline Status in household & 173 & 86.5 \\
Head & 25 & 12.5 \\
Spouse & 2 & 1.0 \\
Sibling & & \\
\hline Level of education & 77 & 38.5 \\
No formal education & 72 & 36.0 \\
Primary & 38 & 19.0 \\
Secondary & 13 & 6.5 \\
Tertiary & 103 & 51.5 \\
\hline Access to credit $($ Yes) & & \\
\hline Source: Fit Survey 2019 &
\end{tabular}

Source: Field Survey, 2019

Results in Table 5 show that there were more males (84.0\%) than females (16.0\%), implying that farmers in the study area were predominantly male and this could be due to the cultural beliefs that males are seen as the stronger counterparts and also, the breadwinners of the family. From the results, $4.0 \%$ were natives and $96.0 \%$ were non-natives, which further explains why only few plots were inherited. This shows the presence of many migrant farmers in the area, and suggests high level of participation in land market.

Majority (96.5\%) of the respondents were married, showing that most of the farmers were settled and had families. This could easily prompt the involvement of the members of their households in their farming activities, thus increasing their labour force and output. This can also increase the likelihood of participation in land market. The highest percentage $(86.5 \%)$ of the respondents were heads of households, and this might be the reason why most of the respondents were actively involved in various livelihood activities because the head of the household has to fend for the household members. It is expected that the more involved they are in livelihood activities, the higher the likelihood of participating more in land market.

From the results, $61.5 \%$ of the respondents had one form of formal education or the other. Education is very important in shaping the intellects of individuals. Also, more than half (51.5\%) of the respondents had access to credit. Access to credit is a very significant factor in enhancing the livelihood activity of any individual. The sources of credit available to the household members include cooperative society, farmers' associations, and friends and family. Access to credit is also expected to facilitate higher levels of involvement in land market. 
Table 6. Statistics of Respondents' Socio-economic Characteristics

\begin{tabular}{|c|c|c|c|c|c|}
\hline Variable & Frequency & $\%$ & Min & Max & Mean \\
\hline \multicolumn{6}{|c|}{ Age of respondents } \\
\hline$<30$ & 2 & 1.0 & 24 & 70 & 48.79 \\
\hline $30-40$ & 25 & 12.5 & & & $( \pm 7.895)$ \\
\hline $41-50$ & 104 & 52.0 & & & \\
\hline $51-60$ & 54 & 27.0 & & & \\
\hline$>60$ & 15 & 7.5 & & & \\
\hline \multicolumn{6}{|c|}{ Household size } \\
\hline$<5$ & 27 & 13.5 & 2 & 13 & 6.42 \\
\hline $5-10$ & 166 & 83.0 & & & $( \pm 2.028)$ \\
\hline$>10$ & 7 & 3.5 & & & \\
\hline \multicolumn{6}{|c|}{ Total land size (hectares) } \\
\hline$<2$ & 107 & 53.5 & 0.2 & 8 & 1.87 \\
\hline $2.00-4.00$ & 85 & 42.5 & & & $( \pm 1.232)$ \\
\hline $4.01-6.00$ & 7 & 3.5 & & & \\
\hline$>6.01$ & 1 & 0.5 & & & \\
\hline \multicolumn{6}{|c|}{ Plot locations } \\
\hline $1-2$ & 199 & 99.5 & 1 & 4 & 1.10 \\
\hline $3-4$ & 1 & 0.5 & & & $( \pm 0.341)$ \\
\hline
\end{tabular}

Source: Field Survey, 2019

The statistics of socio-economic characteristics of the respondents, are presented in Table 6. The highest percentage $(52.0 \%)$ of respondents fell between 41 and 50 years, and average age of 49 years suggests that most of the respondents were in their active and productive years, and they could also cope with the rigours of farming. Also, Majority (83.0\%) of the respondents had household sizes ranging from 5 to 10, and the average household size of 6 suggests the reason for the high level of activities in farming because they had members of households to assist on the farm.

Only $4.0 \%$ of the households held above 4 hectares of land while majority (96.0\%) held less than 4 hectares. The mean farm size was $1.87 \mathrm{ha}( \pm 1.23)$, indicating that farmers were operating on small scale. On the other hand, livestock farmers did not need as much land as crop farmers. Almost all (99.5\%) the respondents had their plots in 1 to 2 locations, and on the average, farmers had plots in one location. This may facilitate effective farming activities. It could also indicate minimal fragmentation of farmland as the average farm size was small.

\subsubsection{Land Market Index}

Results of land market indices $\left(\mathrm{LMI}_{i}\right)$ of households are presented in Table 7.

Table 7. Land Market Indices of Households

\begin{tabular}{lll}
\hline Land market index ( ranges from $\mathbf{0}-\mathbf{1})$ & Frequency $\mathbf{n}=\mathbf{2 0 0}$ & $\mathbf{\%}$ \\
\hline 0.00 & 10 & 5.0 \\
$0.01-0.25$ & 0 & 0.0 \\
$0.26-0.50$ & 1 & 0.5 \\
$0.51-0.75$ & 12 & 6.0 \\
$0.76-1.00$ & 177 & 88.5 \\
\hline
\end{tabular}

Source: Field Survey, 2019

Results in Table 7 show that $5.0 \%$ of the households had land market index of 0 , meaning that the respondents did not participate in land market. These could be the few natives who inherited land or those who got land as gifts. Also, $6.0 \%$ of the households acquired $51 \%$ to $75 \%$ of their land through market while majority $(88.5 \%)$ acquired $76 \%$ to $100 \%$ of their land through market. A household with an index of $100 \%$ simply acquired all plots of land or total farm size 
cultivated through land market.

Table 8. Land Market Indices of Farming Activities

\begin{tabular}{llll}
\hline Livelihood activity & $\begin{array}{l}\text { Total area of land involved } \\
\text { (ha) }\end{array}$ & $\begin{array}{l}\text { Area of land acquired by } \\
\text { market (ha) }\end{array}$ & $\begin{array}{l}\text { Land market } \\
\text { index (LMI) }\end{array}$ \\
\hline Crop farming & 341.80 & 332.00 & $0.97\left(\mathrm{LMI}_{\mathrm{c}}\right)$ \\
Livestock farming & 29.85 & 29.35 & $0.98\left(\mathrm{LMI}_{\mathrm{L}}\right)$ \\
Total land held by households & 370.85 & 361.35 & $0.97\left(\mathrm{LMI}_{\mathrm{h}}\right)$ \\
\hline
\end{tabular}

Source: Data Analysis, 2019

$L M I_{c}=$ land market index for crop farming

$L M I_{L}=$ land market index for livestock farming

$L M I_{h}=$ land market index of all households

The land market indices of farming activities in the study area are presented in Table 8. The total land area involved in crop farming was 341.80 hectares while the area of land acquired through market for crop farming was 332.00 hectares. Therefore, LMI for crop activities with the value of 0.97 explains that $97 \%$ of the land used for crop farming was acquired through land market. Also, the total land area involved in livestock farming was 29.85 hectares while the area of land acquired through market for livestock farming was 29.35 hectares; this gives an index of 0.98 for livestock farming activities, implying that $98.0 \%$ of the land used for livestock farming was acquired through land market. Cumulatively, the total land area acquired by all households was 370.85 hectares while the area of land obtained through market was 361.35 hectares, and this gives a land market index value of 0.97 implying that $97 \%$ of land area used by households in the study area were acquired through market. Land market participation by households was very high.

4.3.4 Factors Affecting the Extent of Participation of Households in Land Market

The results of Tobit regression on the factors affecting the extent of participation of households in land market are presented in Table 9.

Table 9. Factors Affecting the Extent of Participation of Households in Land Market

\begin{tabular}{llll}
\hline Variable & Coefficient & Standard error & $\mathbf{P}>/ \mathbf{t} /$ \\
\hline Sex & $0.1265796^{* * * *}$ & 0.0290756 & 0.000 \\
Age & 0.0027701 & 0.0018236 & 0.130 \\
Immigrant status & $-0.0965585^{* * *}$ & 0.0259959 & 0.000 \\
Years of schooling & $-0.0090992^{* * *}$ & 0.0027209 & 0.000 \\
Household size & -0.0051200 & 0.0053719 & 0.342 \\
Total land size & 0.0114252 & 0.0074766 & 0.128 \\
Income & $1.73 \mathrm{e}-08$ & $2.15 \mathrm{e}-08$ & 0.423 \\
Access to credit & $0.0631405^{* *}$ & 0.0269465 & 0.020 \\
Household status & $0.0600217^{* * *}$ & 0.0189745 & 0.002 \\
Constant & -0.0624001 & 0.1068711 & 0.560 \\
\hline
\end{tabular}

Source: Data Analysis, 2019

***\&** represent significance @1\% and 5\% respectively

The results in Table 9 show that sex had positive significant effect on farmers' participation in land market at 1\%. This simply explains that being a male farmer encourages participation in land market because the man is obliged to provide for the needs of his household and as such, needs to engage in one form of livelihood activity or the other, hence the need to participate in land market. On the other hand, the immigrant status of farmers (being native), though significant at $1 \%$, had negative effect on the participation of farmers in land market. This indicates that been a native of a particular village reduces the extent of participation in land market because most indigenes tend to inherit their farmlands, hence there might be little or no need to participate in land market.

Years of schooling of farmers, though significant at $1 \%$, had negative effect on participation in land market. This indicates that formal education decreases the chance that a farmer will want to continue with farming activities full time, 
and might reduce his participation in land market due to his involvement in white collar jobs. However, farmer's access to credit had positive effect on his participation in land market and this was significant at $5 \%$. This indicates that farmers who have access to credit facilities participate more in land transactions when land is needed in order to generate more income, and this increases their participation in land market.

The household status (being the head) of the farmer had positive effect on the participation in land market and this was significant at $1 \%$. This simply explains that being the head of a household comes with greater responsibilities and obligations. The head therefore needs to provide for his household and as such, needs to acquire more land for food production.

\subsection{Effects of Land Market and Livelihood Income on Welfare of Households}

The results of the multiple regression analysis on the effect of land market and livelihood income on the welfare of households are presented in Table 10.

Table 10. Effect of Land Market and Livelihood Income on Welfare of Households

\begin{tabular}{lllll}
\hline Variables & Coefficient & Standard Error & $\mathrm{T}$ & $\mathrm{P}|\mathrm{t}|$ \\
\hline Age & 0.067 & 761.671 & 0.967 & 0.335 \\
Household size & -0.006 & -267.584 & -0.089 & 0.929 \\
Marital status & 0.004 & 744.818 & 0.053 & 0.957 \\
Land market index & $0.302^{* * *}$ & 121773.063 & 3.891 & 0.000 \\
Total land size & $0.253^{* * *}$ & 1225.284 & 3.413 & 0.001 \\
Access to credit & 0.038 & 6829.603 & 0.586 & 0.559 \\
Immigrant status & $-0.146^{*}$ & -66451.640 & -1.831 & 0.069 \\
Years of schooling & $0.234^{* * *}$ & 4138.425 & 3.575 & 0.000 \\
Household status & $-0.226^{* *}$ & -53068.702 & -2.054 & 0.041 \\
Crop farming & $0.230^{* * *}$ & 32671.071 & 3.219 & 0.002 \\
Livestock farming & $0.336^{* * *}$ & 40771.708 & 2.718 & 0.009 \\
Constant & & 94318.106 & 1.123 & 0.280 \\
\hline
\end{tabular}

Source: Data Analysis, 2016

Note: the symbols ***,**,*represent significance@1\%,5\% and 10\% respectively

Results presented in Table 10 show that land market indices of households had positive effect on their welfare and this was significant at $1 \%$ level. This further shows that involvement of households in land market enabled them to acquire land for their livelihood activities, and this was significant in enabling them to generate more income, positively affecting their consumption and improving their standard of living, thereby improving their welfare. The more the households participate in land market, the better their welfare.

Total land size of households had positive relationship on their welfare as shown in the results. This was significant at $1 \%$. This indicates that the total land size held by households would positively affect their welfare in the sense that the more land they have to carry out their farming activities, the more income they are able to generate, and this improves their welfare status. This implies that increased total farm size will lead to improved welfare. However, immigrant status, though significant at $10 \%$, had negative effect on welfare. Been a native of a particular village reduces their welfare condition. This might be because most natives tend to relax and feel at home without really participating actively in income generating activities that will improve their welfare. This reason further explains why only $4.0 \%$ of the farmers were natives as seen in the descriptive analysis. This could mean that the migrant farmers have better welfare status than the native farmers.

Years of schooling of household head had positive influence on welfare of households and this was significant at $1 \%$. This indicates that higher levels of formal education acquired by household heads made them innovative and able to come up with ideas and livelihood activities that would aid income generation and improve their welfare. Household status, though significant at $5 \%$, had negative effect on welfare. Being a household head comes with a lot of responsibilities, especially, financial responsibilities and this might have a negative effect on the welfare of the household head.

Results show that crop farming in the study area had positive relationship with welfare of farmers and this was 
significant at $1 \%$. This explains that households' involvement in crop farming activities promotes welfare. This can be seen from a priori expectation that a man's livelihood activities should be able to significantly improve his standard of living, and thus, his welfare. The results of the descriptive analysis also helped in ascertaining this claim as it shows that respondents who were involved in crop farming generated an average income of $\$ 53833$ monthly (Table 2).

Livestock farming also had positive effect on the welfare of farmers and this was also significant at $1 \%$. This suggests that households that were involved in livestock activities were able to generate income that improved their consumption expenditure and therefore their welfare. In this study, respondents involved in livestock farming, as seen in the descriptive analysis (Table 2), generated an average income of $\$ 31567$ monthly. Being engaged in both crop and livestock farming improves the welfare of farmers more.

\section{Conclusion}

Rural households engage in various livelihood activities, especially on-farm activities; crop and livestock farming. Households participate actively in land markets (purchase, lease and rent), especially the non-natives. Participation in rural land market enhances crop and livestock farming livelihood activities and the income generated from them. Involvement in land market helps the rural households, especially migrants, to acquire land needed for their daily livelihood activities and this helps to increase their production activities and income generation. Income generated enables them to cater for themselves and household members, positively affecting their consumption and improving their standard of living, thereby improving their welfare. The more the households participate in land market, the better their welfare. Rural land market and livelihood activities have positive significant effects, that is, promote the welfare of rural households.

Participation in rural land market in Southwest Nigeria should be studied more to understand how Government can facilitate formal land markets in rural areas. Also, engagement in crop and livestock farming improves the welfare of rural households; therefore, more rural households should be encouraged to participate in both crop and livestock farming activities. In the same vein, years of schooling plays a significant role in the welfare of rural households; equipping existing schools with adequate facilities and making provisions for adult education and skills acquisition for rural dwellers will go a long way in improving their welfare. Further, involvement of farmers in cooperative societies will enhance access to credit, which will improve their participation in land market and their livelihood, and thus improve their welfare.

\section{References}

Alawode, O. O., Abegunde, V. O., \& Abdullahi, A. O. (2018b). Rural Land Market and Commercialization among Crop Farming Households in Southwestern Nigeria. International Journal of Innovative Food, Nutrition \& Sustainable Agriculture, 6(3), 54-62.

Alawode, O. O., Adewusi, O. A., \& Abegunde, V. O. (2018a). Agricultural Land Market and Commercialization among Crop Farmers in Nigeria. Selected Paper for presentation at the Second Conference of Feed the Future Nigeria Agricultural Policy Project, Transcorp Hilton Hotel, Abuja, Nigeria, August 14-16, pp. 13, 2018.

Alawode, O. O., Olaniran, O. M., \& Abegunde, V. O. (2016). Effect of Land Use and Land Market on Food Security Status of Farming Households in South-Western Nigeria: Evidence from Oyo State. Selected Paper for presentation at the Feed the Future Nigeria Agricultural Policy Project Conference, Abuja, Nigeria, September 27-28, pp. 23, 2016.

Alawode, O. O., Oluwatayo, I. B., \& Abdullahi, A. O. (2017). Income Diversification, Inequality and Poverty among Rural Households in Oyo State, Nigeria. Journal of Economics and Behavioural Studies, 9(5), 83-92. https://doi.org/10.22610/jebs.v9i5(J).1911

Alexander, E. R. (2001) A transaction-cost theory of land use planning and development control: toward the institutional analysis of public planning. Journal of town Planning Review, 72, 45-75. https://doi.org/10.3828/tpr.2001.72.1.45

Antwi, A. (2002). A study of informal urban land transactions in Accra, Ghana. Journal of Agricultural Economics, 13, 34-39.

Arrow, K. (1969). Measuring transaction cost. Journal of Agricultural Economics, 1, $59-73$.

Bamire, A. S., \& Fabiyi, Y. L. (2002). Economic implications of property rights on smallholder use of fertilizer in southwest Nigeria. Land Reform, Land Settlement and Cooperatives, 2, 86-92.

Buitelaar, E. (2007). A transaction-cost analysis of the land development process. Journal of Urban Studies, 41(13), 2539-2553. https://doi.org/10.1080/0042098042000294556 
Burgress, R. (2001). Land and welfare: theory evidence from China. London School of Economics working paper. Journal of Agricultural Economics, 11, 64-71.

Chambers, R., \& Conway, G. (1992). Sustainable rural livelihoods: practical concepts for the $21^{\text {st }}$ century. Discussion paper 296. IDS, Sussex 10(2), 4-12.

FAOSTAT. (2012). Food and Agricultural Organization database. Internet file retrieved from FAOSTAT (Accessed 10/11/2019).

Food and Agricultural Organization of United Nations. (2005). State of food insecurity in the world. Retrieved from http://www.fao.org/hunger/en/ (Accessed 10/11/2019)

Idowu, E. O., Alawode, O. O., Alimi, T., \& Kassali, R. (2007). Analysis of Agricultural Land Market in Ondo State of Nigeria. Bowen Journal of Agriculture, 4(1), 76-93. https://doi.org/10.4314/bja.v4i1.41932

Kironde, S. (2000). Understanding Land market in African urban areas; the case of Dar es Salaam, Tanzania. Habitat International, 24(20), 151-165. https://doi.org/10.1016/S0197-3975(99)00035-1

Lasun, M. O. (2006). Land Reform - Experience from Nigeria: Promoting Land Administration and Good Governance: $5^{\text {th }}$ FIG Regional Conference. Accra, Ghana Retrieved from https://www.fig.net/resources/proceedings/fig_proceedings/accra/papers/ts18/ts1802_olayiwola_adeleye.pdf

Moratti, M., \& Natali, L. (2012). Office of Research working paper wp-2012-No.4.

Olaniran, A. (2015). Participation of farmers in land market in Oyo state. Unpublished MSc. thesis. Department of Agricultural economics, University of Ibadan Nigeria, pp. 71.

Omokhudu, O. (2008). Optimal farm plan and risk in wetland agriculture. Journal of Nigeria Agricultural Development Studies, 1, 7-15.

Oyo State official website. (2019). Retrieved from www.oyostate.gov.ng/about-oyo state

Reardon, T., \& Vosti, S. A. (1995). Link between Rural Poverty and the Environment in Developing Countries. Asset Categories and Investment Poverty. Journal of World Development, 23(9), 1495-1506. https://doi.org/10.1016/0305-750X(95)00061-G

Sallawu, H. L., Tanko, A. A., Coker, A., \& Sadiq, M. S. (2016). Livelihood and Income Diversification Strategies among Rural Farm Households in Niger State, Nigeria. Asian Journal of Agricultural Extension, Economics \& Sociology, 11(4), 1-11. https://doi.org/10.9734/AJAEES/2016/26010

Tobin, J. (1958). Estimation of Relationships for Limited Dependent Variables. Econometrics, 26, 24-36. https://doi.org/10.2307/1907382

Vraken, L. (2002). Ecosystem consequences of biodiversity loss; the evolution of a paradigm. Ecological Society of America journal, 83(6), 1537-1552. https://doi.org/10.1890/0012-9658(2002)083[1537:ECOBLT]2.0.CO;2

Williamson, O. E. (1975). The economics of organization; the transaction cost approach. American Journal of Sociology, 87(3), 548-577. https://doi.org/10.1086/227496

Williamson, O. E. (1996). Markets and Hierarchies: Analysis and Antitrust Implications. 5, 124-137. New York: The Free Press.

Wily, V. (2003). Land use, land cover and soil sciences. Vol III. The value and price of land. Retrieved from http://www.eolss.net/sample-chapters/c19/e1-05-03-03.pdf

World Bank. (2003). Africa Development Indicators, the World Bank Africa database. Washington DC.

World Bank. (2011). Report. Food and Agriculture Organization, electric files and websites. Retrieved from Data.worldbank.org

\section{Copyrights}

Copyright for this article is retained by the author(s), with first publication rights granted to the journal.

This is an open-access article distributed under the terms and conditions of the Creative Commons Attribution license which permits unrestricted use, distribution, and reproduction in any medium, provided the original work is properly cited. 